\title{
Current Condition of Decorative and Applied Art of the Indigenous Peoples Resident in the Territory of the Evenki and Taymyr Municipal Districts (Economic and Sociocultural Practices)
}

\author{
Anastasia V. Kistova and Natalia N. Pimenova* \\ Siberian Federal University \\ 79 Svobodny, Krasnoyarsk, 660041, Russia
}

Received 01.06.2017, received in revised form 02.10.2017, accepted 09.10.2017

\begin{abstract}
The present research outlines the current condition of sociocultural practices of the indigenous peoples of the Krasnoyarsk Territory (Krai), particularly the Evenki and Taymyr Municipal Districts, on the basis of statistic data and field research results provided by top ethnographers and culture scientists, as well as various expeditions carried out by Siberian Federal University.

The article describes present forms of existence of the decorative and applied arts of the indigenous peoples as one of the main means of preservation of the cultural core of the Northern peoples.

Among existing economic and sociocultural practices of preservation of the cultural heritage of the indigenous peoples of the North and Siberia, in the Krasnoyarsk Territory (Krai) there prevail academic ones: museumification, conservation, scientific research and reconstruction. Under the influence of modern and post-modern practices, there develop some other efficient methods of revival and preservation of the cultural heritage of the indigenous peoples.
\end{abstract}

Keywords: decorative and applied arts, indigenous peoples of the Krasnoyarsk Territory (Krai), the Evenki Municipal District, the Taymyr Municipal District.

The reported study was funded by Krasnoyarsk Region Science and Technology Support Fund (the research project "Decorative and applied arts of the Indigenous Peoples of the Krasnoyarsk Territory: Current Status, Prospects for Development").

The reported study was funded by Russian Foundation for Basic Research, Government of Krasnoyarsk Territory, Krasnoyarsk Region Science and Technology Support Fund (the research project № 17-16-24601).

DOI: 10.17516/1997-1370-0149.

Research area: culturology.

\section{Introduction}

The history of studies of the cultural heritage of the indigenous peoples residing in the Krasnoyarsk Territory (Krai) counts several centuries; research and their results can be divided into statistic, socioeconomic and cultural-ethnographic ones.

The contemporariness and continuousness of the researchers' interest for indigenous

(C) Siberian Federal University. All rights reserved

* Corresponding author E-mail address: kistochka7@mail.ru; usataya@yandex.ru 
ethnicities can be explained, first of all, by the fact that the sociocultural practices of such territories are remarkable for the ultimate difference from the dominating ethnicity's lifestyle and tendency to preserve their originality. As a result of today's research activity, we observe development of two contrast views on the cultural heritage of the indigenous peoples expressing both the main disagreement of the modern science on the issue and the conflict of cultural realities. This controversy can be formulated as recognition of the necessity to preserve cultural heritage of the indigenous peoples with simultaneous unacceptability of slowdown in the modernization processes of the changing ethnos.

Generally, folk art research can be of historiographic and conservative kind. These works, written by researchers and the artists themselves, are intended to preserve traditions: classify ornaments, types of products, traditional materials, household items production technologies, specific craft techniques, means of traditional use of various things (Vasilevich, 1969; Makarov, 2007; Mukhachev, Salatkin 2007; Prytkova, 1970; Ivanov, 1963; Ivanov, 2001; Saf'iannikova, 2006; Saf'iannikova, 2008). The bond between folk art, religion, and mythology has been greatly studied on the basis of folklore, fairy tales of the Northern peoples; this is how the folklore of the Evenki, Nenets, Nganasans, Kets, and Dolgans has been collected and partially studied (Amurova, 2004; Brzakova, 2000; Gabysheva, 2003; Geroicheskiy epos dolgan-olonkho, 2008; Grishina, 2010; Mify, skazki, skazaniia mansi, 2005; Muratkasimova, 2010; Oegir, 2006; Peretiatko, 2004; Nenetskiy fol'klor v zapisiakh, 2001; Trifonova, 2006). As for decorative and applied art, there are some examples of studies of the shaman costume ornaments and attributes as a representation of the shamanistic mythological three-element world outlook (Vasilevich, 1969; Mukhachev,
Salatkin, 2007; Nganasans, 2010). Researches of other pieces of decorative and applied arts in the context of religious beliefs of the ethnos are often restricted to some incomplete interpretations or records of comments given by culture bearers, such as artists or shamans (Ammosova, 1994; Volchenko, 2006; Mukhachev, Salatkin, 2007; Ivanov, 1963; Ivanov, 2001; Natsional'naia odezhda evenkov, 1994; Taymyrskie natsional'nye ornamenty; Robbek, Robbek, 2004; Saf'iannikova, 2006). Costume ornaments have also been mentioned as an indicator of the social status of the bearer: his origin, family status, number of children, grandchildren, hunting success (for men). Researcher Oleg Krashevskiy, founder of the Ethnography Museum on Lama Lake, provides an example of a parka for a 5-8 year old girl decorated with a single ornament piece indicating her belongness to a certain family, and remarks that after each significant change in the girl's life the ornament will be completed with new details (Nganasany, 2010). Nevertheless, today this knowledge is considered to be almost lost, and decorating parka with ornaments is seen as a tradition, without its initial meaning.

The most consistently development and sustainable opinion on the cultural heritage of the indigenous ethnoses of the North and Siberia, and the Krasnoyarsk Territory (Krai) in particular, is the one claiming it to be unique and tragically extincting. This approach, shared by the majority of the Soviet ethnographers, calls for preservation and protection of the cultural heritage of the indigenous peoples, especially the smallnumbered ones. This position was the starting point for large ethnographic collections of the greatest Russian and regional museum centres. Thus, ethnographer I.S. Gurvich writes that one of the consequences of joining the Siberian North to Russia was "breaking the centuries' long isolation of the Northern peoples" from the society of a higher development level, which 
ensured preservation of their unique cultures (Etnicheskaia istoriia narodov Severa, 1982). This approach recognizes such means of cultural heritage preservation as various methods of fixation and revival of the indigenous traditions: active museumification of various aspects of the cultural heritage (museum collections and expositions), conservation of non-material cultural heritage (folklore, language), as well as heritage restoration technologies (compilation of dictionaries, records of writing, implementation of education projects).

The alternative opinion claims that the means of preservation shall not lead to "museumification of the people" or push the indigenous peoples away from the path of their natural and necessary changes. Sociologist V.V. Simonova draws attention to the fact that modern Russian society tends to romanticizing culture, therefore, refusing to recognize indigenous peoples in their contemporary routine condition, but turning their past mythology into the "model of the desired social structure" (Simonova, 2008: 69-70). On one hand, romanticization of the peoples' past is understood as cultural nostalgia; on the other, the researcher writes, it proves nationalistic spirits both "inside" and "outside". Relying on collected field research materials, the researcher comes to conclusion on the unfair lack of attention to culture romanticization, for they are an actual tendency tightly bound to the problems of nationalism, cultural distance, identity, and leading to misunderstanding of modern social tendencies, calling for preserving traditional culture bearers, but ignoring indigenous peoples as people in their contemporary changing form. Such conceptual opinion is typical for both Russian post-Soviet ethnology and foreign researchers. This opinion was expressed by P. Rethmann (Rethmann, 1997), H.O. Habek (Habek, 2005), M.W. Khakkaraynen (Khakkaraynen, 2007), Iu.L. Slezkin (Slezkin, 2008), M.S. Kuropiatnik (Kuropiatnik, 2006).
Researcher of the Evenki and Dolgans of Khantayskoe Ozero village (Taymyr Autonomous District of the Krasnoyarsk Territory (Krai)), Canadian ethnologist D.J. Anderson, remarks a giant gap between the image of the indigenous peoples commonly known from classic researches and their real representatives who have made their choice in favour of future, not the past, and modern sociocultural processes very long ago (Anderson, 1998).

The conflict of the two opinions on the cultural heritage of the indigenous peoples, and particularly, of the ethnicities resident in the Krasnoyarsk Territory (Krai), slows down all discussions of any mechanism of involving the cultural heritage into the peoples' daily life. The ones suggested by the first group of researchers seem to be inefficient, while the second opinion practically denies any opportunities of maintaining traditional sociocultural practices, claiming the inevitability of the cultures' modernization. Nevertheless, even in the situation of progressive changes, global phenomena prove high adaptability of many ethnical traditions.

Both Russian and international researchers have witnessed this component of ethnical heritage functioning as a means of ethnic identity support, some examples of including ethnoreligious practices and ethnic art being efficient mechanisms of ethnos reproduction. Such examples are territorial brands, national symbols, trademarks of regional manufacturers and social organizations' logos, acceptance of the national costume in some official situations, synthetic practices of museums and ethical reserves. Ethnos residence territory branding is an efficient identity-developing practice involving ethnical heritage as a tradition (Savel'ev, 2011; Kotler et al., 2005; Kanyba, 2013; Naumov, 2012; Mal'kova, Tishkov, 2010). Such sociocultural post-modern practices as territorial marketing technologies are efficient with regard 
to identity-developing function of the ethnical heritage, for national positioning of the people. Besides territory brands, those may also be coats of arms and flags, registered symbols and other attributes. They may also include corporate styles and logos of regional manufacturers and social organizations using any ethnical components, such as national costume elements.

Another interesting example of integrating sociocultural practices of indigenous ethnos into modern and post-modern practice is ethnic villages. Those are commercial projects in the sphere of ethnotourism intended to restore ethnical heritage of indigenous people in the form of daily life routine for a group of its representatives, developing image of the indigenous peoples recognizable by ethnical group members through symbolism, traditional household items, pieces of art and activities. All these elements create the brightest and fullest image of its own identity for the modern generation of the local population identifying itself with the indigenous ethnicity, and of an original ethnic community for representatives of other ethnicities.

\section{Methods}

This research is based on the principles of system analysis, conceptual provisions of constructivist approach to cultural identity, visual art theory by V.I. Zhukovsky and N.P. Koptseva (Zhukovsky, 2011; Zhukovsky, 2010).

The research of functioning of the original cultural heritage of the small-numbered indigenous peoples of the Krasnoyarsk Territory (Krai), besides all the variety of phenomena and facts, is based on scientific research of the ethnical situation in the region. It relies on results of expeditions carried out by Siberian Federal University within the framework of grant projects in the Krasnoyarsk Territory (Krai) and places of residence of the indigenous peoples (Kolesnik, 2016; Koptseva, 2014a; Koptseva, 2014b;
Koptseva, 2015; Koptseva, 2016; Krivonogov, 2013; Libakova, Petrova, 2016; Reznikova, 2013; Reznikova, 2014; Sitnikova, 2016; Reznikova, 2017; Koptseva, 2017; Gavrilov et al., 2017; Korovushkin, 2017; Mandryka, 2017; Zamaraeva et al., 2017; Libakova et al., 2017; Seredkina et al., 2017).

The analysis of the modern situation of the cultural heritage of indigenous peoples rightfully considers the data on the number and distribution of the ethnos' representatives, dynamics of their latest indicators, shares of urban and rural population within the ethnicity. These indicators may, to some extent, be used to forecast the degree of ethnocultural loss and suggest, which sociocultural practices, traditional, industrial, or post-industrial, would be wider spread among members of the ethnic communities.

\section{Evaluation of modern sociocultural practices of the indigenous peoples of the Krasnoyarsk Territory (Krai)}

In accordance with the results of statistic and field research, the small-numbered indigenous peoples of the Krasnoyarsk Territory (Krai) are diverse communities maintaining a wide range of various sociocultural practices today.

Modern combination of sociocultural practices typical of various communities (premodern, modern, post-modern) suggests, that the process of revival and preservation of cultural heritage also requires lots of variants of integrating pre-modern, modern and postmodern social practices. According to the last census of Russia, the number of representatives of indigenous peoples of the Krasnoyarsk Territory (Krai) resident in the rural area exceeds that resident in the urban one at least by 2 (Evenki), or even by 17 times (Chulyms) within one ethnos (see Table 1).

It means that communities of indigenous ethnicities of the Krasnoyarsk Territory (Krai) 
Table 1. Table of distribution of small-numbered indigenous peoples of the Krasnoyarsk Territory (Krai) between rural and urban areas according to the official published data of the All-Russian Population Census of 2010

\begin{tabular}{|l|c|c|}
\hline $\begin{array}{c}\text { Small-numbered indigenous peoples } \\
\text { of the Krasnoyarsk Territory (Krai) }\end{array}$ & $\begin{array}{c}\text { Urban population } \\
\text { (number, people) }\end{array}$ & $\begin{array}{c}\text { Rural population } \\
\text { (number, people) }\end{array}$ \\
\hline Dolgans & 1452 & 4358 \\
\hline Kets & 173 & 774 \\
\hline Nganasans & 263 & 544 \\
\hline Nenets & 657 & 2976 \\
\hline Selkups & 70 & 211 \\
\hline Chulyms & 8 & 137 \\
\hline Evenki & 1345 & 3027 \\
\hline Enets & 53 & 167 \\
\hline
\end{tabular}

mostly keep to the integration of traditional and industrial societies' sociocultural practices with the minimum of post-modern technologies and correlate with the "indigenous peoples" subgroup within the scale from peoples living their traditional lifestyle to the people living the lifestyle typical for all average Russian village.

According to the results of the expeditions carried out by the culturology department staff of Siberian Federal University, the phenomenon of trading stations, reindeer breeders' camps still widely spread in Evenkia, Turukhansk District proves that some fractions of the indigenous peoples resident in the said territories have minimally deviated from their traditional lifestyle, therefore, they still stick to pre-modern cultural practices integrated with $3 \Phi 430$, some modern ones (for instance, they have definitely implemented such elementary economic practices as monetary relations). The indigenous peoples living traditional Russian rural lifestyle constitute a sub-community that has been assimilated the most, combining pre-modern and modern cultural mechanisms with the latter dominating. A bright example is the situation of the Chulyms of the Krasnoyarsk Territory. According to the field observations of the year 2010, in the life of the people modern sociocultural practices prevail. Thus, on one hand, traditional fishing is a popular economic activity, and it still uses traditional boats (chiseled oblaskas) and some fishing accessories. At the same time, fishing is not a matter of survival anymore; this activity is now involved into the market relations: every Monday morning, a bus with locals and their weekend catch leaves from Chindat village council to Tyukhtet administrative centre. Fishing today is a means of making a living, a wide-spread modern economic practice. The same need to take part in the market relations develops the chain of the rural populations' dependency on their earnings factor. As a result, the Chulyms themselves claim almost total unemployment, the population registers with the Employment Centre for getting allowance, lots of young people lose themselves into drinking, as they say, "for having nothing else to do", with others struggling to move to the district or regional centre for any education or a job (Korennye malochislennye narody Severa..., 2012).

The results of the Siberian Federal University expeditions to other territories of residence of the small-numbered indigenous peoples also prove that pre-modern practices do not dominate in the lives of their representatives, and in a series of cases they are denied and traditional activities' and social tools' being replaced with modern ones by the peoples themselves. Thus, the results of the 
first expedition to Turukhansk District of the Krai (2010) showed that the indigenous population does not have the desire to maintain their cultural heritage; they encourage assimilation, moving away from the traditional places of residence, believe that studying their ethnic language is useless (Korennye malochislennye narody Severa..., 2012: 531-550). The situation observed in Evenkia was completely different: with the total desire for better life, technical and technological innovations, researchers noticed greater interest of the Evenki in preserving their own cultural heritage. It is proven by the wide use of ethnic language and intention to teach the language to children, high development level of reindeer breeding as a traditional economic activity, significance of deer in the everyday life (means of transport, food and income) (Korennye malochislennye narody Severa..., 2012: 492513). However, all these traditional practices are actively modernized by means of modern (techniques, technologies, market relations) and post-modern ones. The minority of the indigenous ethnicities involved into integrating all these types of social practices to different extent, is the "urban national minorities" subgroup. According to the field research carried out in the Krasnoyarsk Territory (Krai), a prominent "protonation" group of the indigenous population, efficiently using both modern and post-modern practices in order to reconstruct their ethnic identity (with any inclusion of pre-modern cultural practices), is found in the communities of Evenki and Chulyms. In different ethnoses this subgroup can be active to different degrees. Among the Chulyms, there is only one family, or, to be more precise, the head of this family who occupies an active position on the revival and reconstruction of the ethnical identity (Korennye malochislennye narody Severa..., 2012). Resident in Pasechnoe village, A.F. Kondiakov collects all information on the Chulyms, their origin, arrival to the Chulym River banks, as well as folklore records, ethnical tales and legends (Krivonogov, 2008). The people of Evenki has some socially active economic and political leaders, with the intellectual elite actively engaged in the studies of its origin and revival of traditional economic activities for commercial purposes.

\section{Decorate and applied art \\ of the indigenous peoples of the Evenki and Taymyr Municipal Districts}

In the XX century, decorative and applied art traditions of the northern ethnicities have earned its status of a Northern lifestyle symbol, i.e. modern and post-modern practices have caused recognition of traditional arts and crafts as symbols of the indigenous peoples in general. This tendency is greatly encouraged by growing touristic interest: traditional arts, crafts and items are transformed into souvenirs made for the market, involving traditions into modern and post-modern sociocultural practices. It is also proven by the popularity of ethnic farmsteads and "craft fairs" at local celebrations in Krasnoyarsk and other towns of the region, as well as festival events ("World of Siberia"). However, such way of reviving and preserving decorative and applied art traditions of the indigenous peoples of the Krasnoyarsk Territory (Krai) as inclusion of its techniques and technologies into the education curriculum as a regional component, is not used in the region. Similar experience was described by the Herzen State Pedagogical University of Russia, which specializes in training teachers of ethnic languages of the indigenous peoples in the North, in Siberia, and Far East. Since 2002, the university has launched a teachers' training course in artistic practices of the indigenous peoples in the class of decorative and applied arts and crafts of the peoples of the North, Siberia and Far East. According to the university's website, education is based on adaptation of 
tradition to modern conditions; classes are targeted at "finding ways to combine traditional and contemporary material, ways of actualizing ancient artistic techniques that have emerged in a different, often lost cultural context" (official website of the Institute of the Northern Peoples of the Herzen State Pedagogical University of Russia). At the same time, professional art of the Krasnoyarsk Territory (Krai) witnesses mutual influence of the cultural practices of pre-modern, modern and post-modern: penetration of the artistic traditions of the indigenous peoples into professional artists' activities. Ethnic traditions enter the artistic language of various authors regardless of their belonging to small-numbered indigenous peoples of the North and Siberia. An example of such artistic practice is the art of Nganasan Motumiaku Turdagin and a number of Krasnoyarsk artists, including one of the founders of Krasnoyarsk art school Dmitry Innokentyevich Karatanov, Andrei Prokofyevich Lekarenko, who took part in the Turuskhansk expedition for transpolar population census, Vladimir Ilyich Meshkov, Konstantin Semenovich Voynov (Semenova, Bralkova, 2011). At the same time, as folk craftsmen continue their activities, it is interesting how three kinds of sociocultural practices integrate into their experience. Typical traditional family succession of craft "from father to son" has transformed into experience transfer within small social groups (clubs, workshops) concentrated on their individual preferences, which is typical for modern situation. At the same time, artists themselves often introduce a reflective element into their artistic practice to implement such modern sociocultural practice as getting systemic knowledge of their own cultural reality.

Justly like Soviet ethnographers' works, the main contemporary researches are of historiographic, conservative character, with the studies intended to preserve the traditions: classify ornaments, types of items, traditional materials and their manufacturing techniques, technologies of making household items, specific craft techniques, ways of traditional use of various things (Prytkova, 1970; Ivanov, 2001; Ivanov, 1963). Activities of the decorative and applied arts' masters can be described in a similar way. Among all peoples of the Krasnoyarsk Territory (Krai), Evenki play the most active part here. The woks of T.M. Saf'iannikova, an Evenki applied art seamstress (Saf'iannikova, 2006; Saf'iannikova, 2008), present an attempt to encompass all peculiarities of the Evenki as a nation, among which the dominating role is assigned to language, forms of art and specificity of life under the severe natural conditions. According to the author, these are the features that define the Evenki as a special nation, their qualities as of bearers of the culture, and, particularly, language, art, crafts, and their original lifestyle.

At the same time, researchers remark different degree of involvedness of national costume into the everyday life of peoples or family events. V.P. Krivonogov's interval surveys show, that in the 2000-s the national costume situation was diverse. Some nations have lost this aspect of their cultural heritage. It is widely spread to use some separate elements of the costume: it is typical for the Chulyms (normally, these are not decorative and applied elements, but plain working footwear), or, vice versa, the national costume elements are not used daily, while some people still keep the full costume set $(6.3 \%$ of population for the Nganasan, 1-2 people for the Kets). The Dolgans claim that 24.5 $\%$ of them have the full national costume, while almost $70 \%$ of the Nenets, despite their neglect for traditional activities, keep national costume in their possession. Among the studied nations, the leaders in the national costume keeping are the Evenki. The uniqueness of their situation is that their national clothes is still massively produced; 
it means that the pre-modern practices concerning the original Evenki culture still function in the minimally transformed way, getting into symbiotic relation with post-modern tendencies, as the way of self-assurance of the society through the visual signs of the ethical culture. The share of the produced ceremonial traditional clothes has increased. The survey showed that wearing traditional costume is popular among the Evenki youth: $48.1 \%$ of the young men and $51.4 \%$ of girls have the complete national costume set. Such degree of actualization of the national costume as an aspect of cultural heritage leads to the conclusion on the high degree of its preservation and optimistic forecasts for the future. Simultaneously, the Evenki like making their family collections including folk costume attributes as family relics as well as other inherited items of ethnical crafts. In practice (mostly, at celebrations) there are replaced with new things. That is an obvious form of household museumification, development of the individual image of the family, people, and their belonging to the ethnos as typical sociocultural modern and post-modern mechanisms.

Despite the small share of the traditional clothes preserved by the Nganasans, the Ethnography Museum on Lama lake has a large costume collection (mostly consisting of parkas) made up in the recent years: in the 19902000s. The collection also has the parka, which, according to O. Krashevsky, is presumably the last one sewn by the Nganasans: it was sewn in 1996 by one of the last Nganasan seamstress Ekaterina Momde as a present for the museum owner (Nganasany, 2010: 20-21). Along with that, the museum catalogue points at one of the semantic aspects of the Nganasan parka ornament. The horizontal lines of the ornament ribbons of geometric elements (muli) in the lower part of the parka have traditionally served as a "passport": their signs meant the family, marital status, number of children, success in work etc. Thus, a parka belonging to a 5-8 year old girl has only one ornamental ribbon, which, presumably, only indicates her family belonging (Fig. 1, 2). However, a parka of a 8-12 year old girl has two ornamental ribbons; the second one meant that the girl is already learning how to help her mother (Fig. 3, 4).

It is an example of a Nganasan tradition, according to which new ornamental elements were added to the parka after each significant event in the person's life. By the end of the $20^{\text {th }}$ century, this tradition began to be neglected, and the knowledge of the ornamental language was also lost. Thus, O. Krashevsky remarks, that the ornaments on the parka sewn in 1996 bear exclusively decorative meaning. The absence of the critical element, the metal item in the centre of the composition, in recently made pouches means that they have been made by the craftsmen who was not longer competent in the meaning of the pouch decorative elements. While the majority of the pouches in the Museum collections are good examples of the tradition, there is one that does not keep to it any more. The knowledge of the meaning of the ornament on the metal sheath is also lost; none of the respondents (presenters of the item, other ethnos representatives) could explain the layout or the meaning at least of some certain elements of the composition. At the same time, we should notice the stability of decorative compositions used on household items and clothes of the indigenous peoples of the Krasnoyarsk Territory (Krai): researchers remark minimum modifications of the ornaments used by the indigenous peoples, which is explained by their respect for tradition and care for the things made by the previous generation as canonic (Vasilevich, 1969; Ivanov, 1963; Saf'iannikova, 2008).

The care for the artistic tradition and its items shown by the small-numbered indigenous peoples 


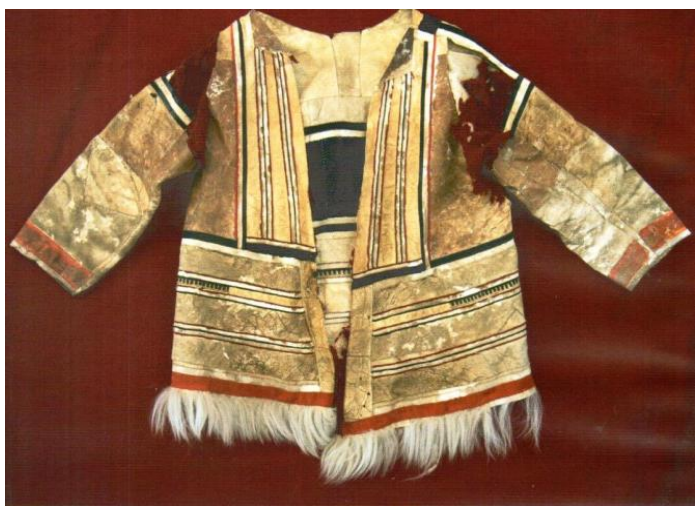

Fig. 1. Parka for a 5-8 year old girl from the front. Ethnographic Museum on Lama lake

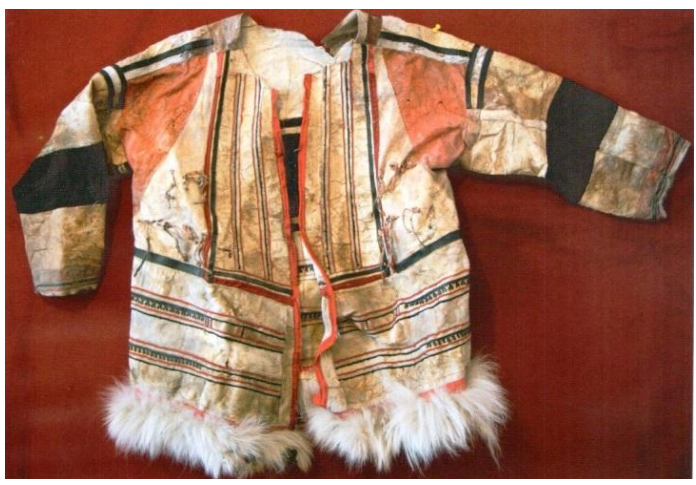

Fig. 3. Parka for a 8-12 year old girl from the front. Ethnographic Museum on Lama lake

of the Krasnoyarsk Territory (Krai) is proven both by the good condition of the frequently used items and the fact of multiple restoration carried out by the items' owners. For example, the large traditional jewellery collection that has been used by the Nganasans for a long time and currently kept at the Ethnomuseum on Lama lake, contains some items that easily combine some details of the past with the contemporary ones, still preserving the compositional integrity of the item's initial ornament. All losses of ornaments have been carefully restored for the things to be used for longer time. A good example is several traditional ceremonial hats that any girl had to wear since the moment she comes to the age; in their ornamental compositions, we can find buttons belonging to

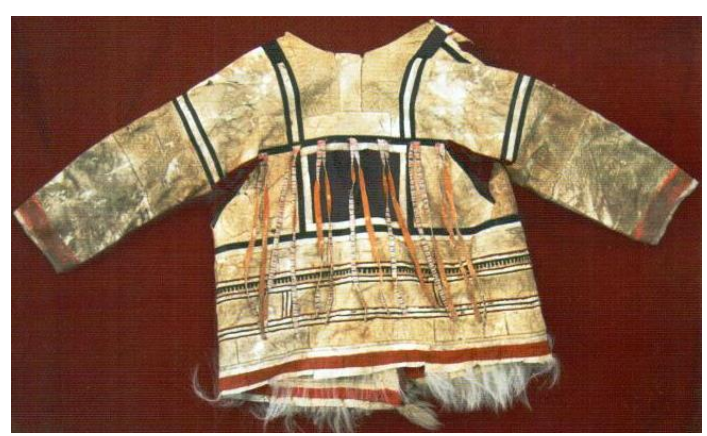

Fig. 2. Parka for a 5-8 year old girl from behind. Ethnographic Museum on Lama lake

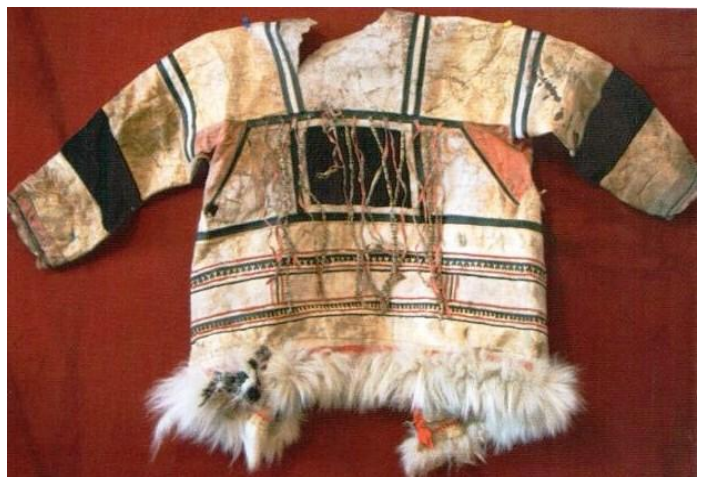

Fig. 4. Parka for a 8-12 year old girl from behind. Ethnographic Museum on Lama lake

various historical ages, from Russian ones of the $14-16^{\text {th }}$ centuries and pre-revolutionary ones to the late $20^{\text {th }}$ century's buttons (Nganasany, 2010: 79-83). Traditional lady's items, such as needle holders with pendants and clinking pendants for women's pouches, combine details belonging to various epochs, obviously used by several generations of owners. Similarly, sheath belts could be inlaid by both pre-revolutionary and contemporary buttons (Nganasany, 2010: 176-178). Exhibits of ethnography department of Krasnoyarsk State Museum of Regional Studies include some items with long history, carefully maintained by their owners, with some lost parts replaced with modern ones. For example, there are some Yakut and Dolgan belts with such fate. 
At the same time, it would be wrong to say that due to the loss of knowledge on the meaning of ornamental elements by the representatives of the ethnos, the things decorated in the traditions of the small-numbered indigenous peoples of the Krasnoyarsk Territory (Krai) do not perform their function of translating the people's ethnoreligious world outlook. This knowledge can be restored: academic science has taken some measures for recording and reconstructing the knowledge, while transparent logic of the traditional items' ornaments is so obvious that its initial meanings are not hard to retrieve.

The ornamental decoration of the ethnical costume still performs a protecting function: as the Evenki craftsmen explain, clothes is decorated along the edges, bottom, and tail. The Evenki still preserve the tradition of careful decoration of the

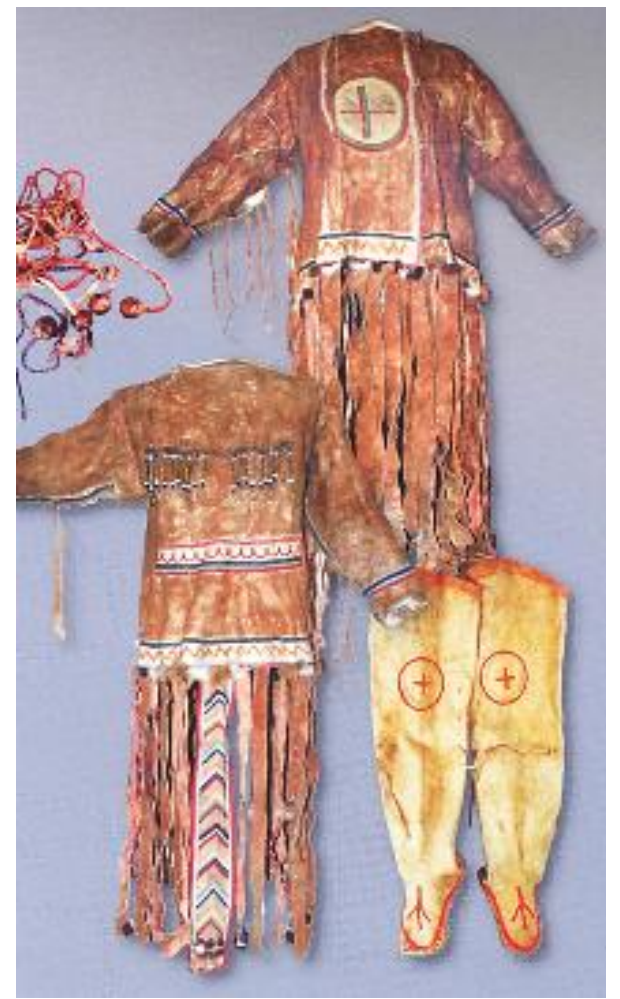

Fig. 5. Jacket and footwear of a shaman. Dolgans, mid$20^{\text {th }}$ century. Taymyr District Museum of Regional Studies burial (Evenki: khallasik) and wedding dressings, wedding presents (dylachakan, kumalan). The seams are carefully sealed and sometimes covered with a strip of cloth to prevent penetration of any evil spirits, i.e. unpredictable spirits from the Lower World. From the point of view of translating the ethnoreligious world outlook of the small-numbered indigenous peoples of the Krasnoyarsk Territory (Krai), the world model is easily interpreted in the shaman costume from the collection of Taymyr District Museum of Regional Studies in the town of Dudinka (Fig. 5) (Predmety shamanskogo kul'ta..., 2008; Official website of Taymyr Museum of Regional Studies). The jacket and footwear of the shaman belong to the Dolgan heritage and describes the basics of the mythological cosmos of the Northern ethnicities: reindeer chamois footwear contains two plain

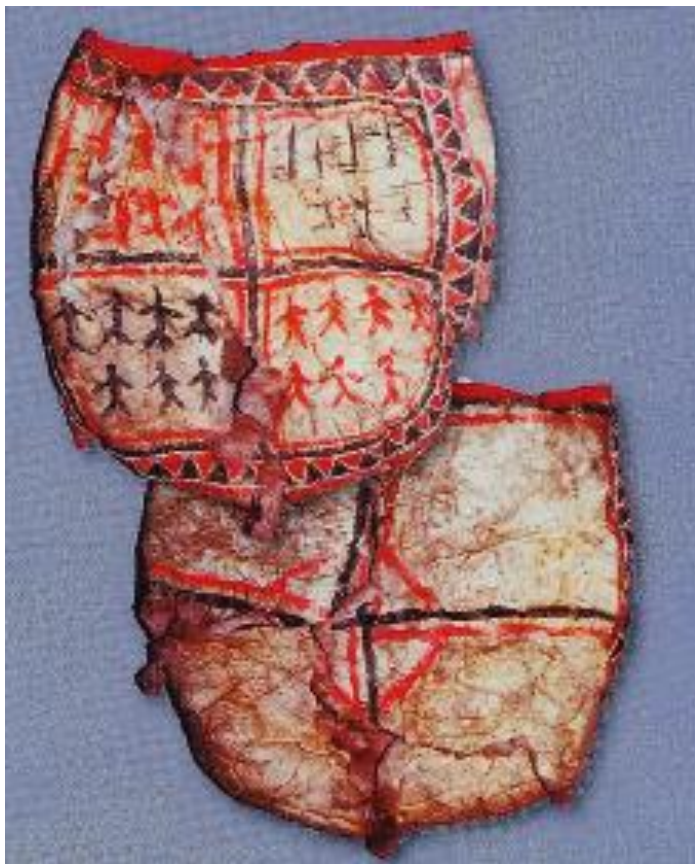

Fig. 6. Shaman's drum case, Nganasans, early $20^{\text {th }}$ century. Taymyr District Museum of Regional Studies 
symbols: a cross inside a circle in the knee area, also duplicated on the jacket chest, and a threepointed crotch on the external side of the foot. Traditionally, in the Northern peoples' semantics, a cross stand for the creator, the demiurge. Being inscribed in a circle means the unity of the creator and the solar element, the synthesis of the deities of the Upper World. At the same time, a circle divided into parts by a cross, usually presents the sacred structure of the world, consisting of the Upper and the Lower worlds, divided into the positive right and the negative left sides. However, in this case the two parts of the world are marked with two colours: red for the Upper, black for the Lower. In such a situation the cross and the circle are coloured one over another, and in the sectors of the circle there are some straight-standing red figures representing the spirits of the Upper world and crooked, broken black figures representing the spirits populating the Lower world (Fig. 6). In the signs of this costume, nevertheless, we also observe duplicating line of red and green colours, opposite in the colour spectrum. We can say that it is a synthetic sign describing both the structure of the sacred world and the one who is the dominant and protecting figure in it, the creator and the sun, the residents of the Upper world. It is also proven by the materials the costume is made of: the jacket and the footwear are made of reindeer fur and chamois, which means that it was used by the shaman for calling the celestial spirits, for travelling to the Upper world. The three-pointed sign on the external side of the foot is a traditional symbol for a foot of a loon or a swan; it is not a coincidence that the shaman jacket is so carefully lined with long fringe of fur and reindeer chamois. The bird image in the shaman costume is emphasized with the fringe on the lower seam along the sleeve imitating the wing feathers, as well as a wide ornamented ribbon of a row of small angles traditionally standing for feathers, also imitating a bird's tail. The jacket back is also decorated with ribbons of water (chain of semicircles) and fire (chain of angles) ornament and the horizon lines of the earth. Therefore, the shaman's costume represents the unity of the Upper world and its dominance in the relations with the Lower one, guarantee of protection and easiness of communication between the shaman and the celestial spirits, as well as the easiness of his travel to the spirits (bird symbols).

\section{Current economic and sociocultural practices of preserving and developing decorative}

\section{and applied arts of the indigenous peoples of the Krasnoyarsk Territory (Krai)}

Looking at possible interpretation of the works of the Northern craftsmen, we can see that with the right use of the tradition, both items of the past epochs and contemporary items of the national decorative and applied arts can represent the mythological cosmos model of the indigenous peoples of the Krasnoyarsk Territory (Krai). Such elements of the cultural heritage can potentially carry the original world outlook of the ethnos, their culture, restoring or preserving the ethnical identity of the community. At the same time, decorative and applied art is the aspect of the cultural heritage able to translate the traditional world outlook of the small-numbered indigenous peoples of the Krasnoyarsk Territory (Krai) and act as a means of bringing it into the life of the people who do not practice shamanism in any way, do not belong to any religious confession or any religion at all.

The role of the special social and cultural institution for preservation and protection of the cultural heritage of the small-numbered indigenous peoples of the Krasnoyarsk Territory (Krai) has been played by museums as scientific, research and exhibition centres in the sphere of ethnography. The Krasnoyarsk Territory is rich in ethnographic collections of the heritage of all 
indigenous peoples of the region both in the regional centre and other towns, created as educational centres upon the initiative of the first owners of the collections. Among the oldest museums of regional studies possessing large collections for the ethnography of the indigenous peoples of the region, there are Krasnoyarsk State Museum of Regional Studied (since 1889), Minusinsk Museum of Regional Studies named after N.M. Martyanov (since 1877), Yeniseisk Museum of Regional Studies named after A.I. Kytmanov (since 1883), Achinsk Museum of Regional Studied named after D.S. Kargapolov (since 1887). The greatest centre of ethnography is Taymyr Museum of Regional Studies in the town of Dudinka; some significant ethnographic collections on the culture of the indigenous population of the region are kept at the Turukhansk District Museum of Regional Studies (Turukhansk), Evenki Museum of Regional Studies (Tura village), Taymyr Reserve Museum of Nature and Ethnography (Khatanga village). The oldest and the largest museums of the region are remarkable for the perfect systematization of their ethnographic material; they are perfect examples of academic approach comparable to the largest scientific museum centres of Russia. Krasnoyarsk Museum of Regional Studies owes its rise to the activeness of its employees. Ethnographer M.S. Batashev and archaeologist N.P. Makarov together with D.J. Anderson and other colleagues have studied and published materials of the largest field research of the indigenous peoples of the Krasnoyarsk North, Turukhansk expedition of the Transpolar Population Census. Based on these data and the museum collections, the scientists have developed a systematic description of the culture of the indigenous nations of the Yenisei Region (all small-numbered indigenous peoples of the Krasnoyarsk Territory (Krai), except for the Chulyms) (Turukhanskaia ekspeditsiia Pripoliarnoy perepisi..., 2005; Makarov, 2007; Batashev, 2013; Makarov, 2013a). The systemized character of description helps distinguishing sociocultural practices of each indigenous ethnos in six spheres: economic activity, material culture, social organization, family rituals, world outlook and cults, spiritual culture. The sources for such generalization are not limited to the field research data, but also include results of regular archaeological expeditions to the Northern areas of the Krasnoyarsk Territory (Krai) carried out by the leading specialist of Siberian Federal University, including N.P. Makarov, P.V. Mandryka (Makarov, 2013b; Mandryka, 2008; Mandryka 2007). This systematic picture of the indigenous peoples of the Krasnoyarsk Territory (Krai) lays in the foundation of the ethnographic exposition of Krasnoyarsk Museum of Regional Studies. The museum in the city of Krasnoyarsk has a rich collection of artefacts belonging to indigenous peoples of the region and a separate exposition dedicated to shamanism practiced by the peoples. The expositions are conceptually based on the academic approach, but they are majorly targeted at making up an individual "historical route" (Il'beykina, 2013): the comprehensive image of each ethnos is formed by modelling the cultural environment considered to be one of the leading means of ethnoculture presentation (Diianova, 2012). Thus, the ethnography of the indigenous peoples of the Krasnoyarsk Territory is presented by a complex with an exposition dedicated to the ancient civilizations on the Yenisei river banks, helping the visitor understand the relations, compare the artefacts belonging to different cultures through the similarity in the cult forms of the ancient civilizations of the Northern and Siberian peoples. At the same time the expositions dedicated to the ethnography of the indigenous population of the region are aimed at making up a comprehensive image of the ethnicity. For this purpose, besides careful classification of the items, a visual element is introduced: the exposition includes some mannequins, anthropologically 
characterizing representatives of this or that people, as well as reconstructions of their traditional houses, an Evenki chum and a Dolgan balk, with regard to the specific construction and adornments. A separate exposition is dedicated to the Yenisei shamanism with another strong element of presence imitation: the shaman costumes and attributes of five peoples are displayed on the mannequins imitating a joint shamanistic ritual. The museum also brings the cultural heritage of the indigenous people of the Krasnoyarsk Territory (Krai) to life through education technologies. For several years, the museum has been running an education programme titled "The Yenisei Region Peoples in the $17-20^{\text {th }}$ centuries. Material and Spiritual Culture". The curriculum includes some events where the listeners learn various aspects of the cultural heritage of the indigenous population of the Krasnoyarsk Territory (Krai), from traditional economic activities to arts and beliefs (Krasnoiarskiy kraevoy kraevedcheskiy muzey..., 2002). The curriculum is a cycle of eight events, each of which is dedicated to one ethnicity, and one - to the shamanism of Siberian peoples. The excursion classes include some games and academic techniques, such as filling in a table in the process of the programme, and a quiz at the end of the cycle. It should be noticed that education as a mechanism of actualization of the cultural heritage of the indigenous population of the region is brought to the fore at the museums in the districts of the region, in small settlements and places of residence of the small-numbered indigenous peoples. In the Krasnoyarsk Territory (Krai), local museum centres are actively introducing the educational programmes into their daily activities. For example, Taymyr Museum of Regional Studies (Dudinka) carries out an educational programme for schoolchildren "Folk culture world" in the culture of the indigenous nations of the Taymyr Peninsula. It is a cycle of nine interactive classes dedicated to traditional celebrations, jewellery, clothes, beliefs, houses, games and toys, carried out at the museum expositions. The programme is greatly sought for by the schools of Dudinka and other settlements, including Norilsk, Talknakh, Kayerkan. Turukhansk District Museum of Regional Studies carries out a cycle of lectures titled "Culture and Everyday Life of the Turukhansk Northern Peoples". Taymyr Research Museum of Nature and Ethnography also provides a cycle of lectures "Regional Studies Classes" for schoolchildren from Khatanga village, as well as a series of educational excursions for students ("Tranditional Dolgan clothes", "Culture and traditions of Nya people", "Culture and everyday life of the Taymyr peoples", "Household items of the Taymyr nomads"). Evenki Museum of Regional Studies also has experience of educational excursions in the Evenki, Essey Yakut, Ket ethnography (including "Chum as a traditional Evenki house in the $19-20^{\text {th }}$ centuries", "Decorative and applied art of the Evenki of the 19-20 $0^{\text {th }}$ centuries", "Culture and everyday life of the Evenki in the $19-20^{\text {th }}$ centuries") besides a continuously working lecturing facility.

Just like other regional museum centres, Krasnoyarsk State Museum of Regional Studies uses academic practices to preserve the cultural heritage of the indigenous peoples (collecting, systemizing of material, storage, exhibition), including traditional cultural forms of the indigenous peoples into post-modern practices, i.e. into creating an integral and tangible image of the people by comparing it to the previous cultures, involving special exhibition technologies and educational practices. In this situation, actualization of the cultural heritage means ultimate integration of tradition and postmodern sociocultural practices, as the population of the regional capital are the people actively involved into post-industrial social life.

Another way of including ethnical traditions into the synthesis of modern and post-modern 
practices is the development of information and communication technologies. Museum technology researchers discuss the efficiency of such adaptation of the museum functions to the needs of the information society. Information and communication technologies may help preserving and translating the ethnical cultural heritage by means of partial representation of the collection (presentation of some exhibits with a proper description) or a virtual tour around the exposition at the museum website. Krasnoyarsk State Museum of Regional Studies and other oldest ethnographic museum centres of the region have their official websites, but their content is only used for the attraction of visitors to the museum facility. Virtual excursions, as well as partial exhibition of the collection online, are scarce in the region. An example is the virtual tour around Krasnoyarsk State Museum of Regional Studies accessible at the official website of the facility. Despite the accessibility of the ethnographic exposition online, we can say that today's form of the virtual tour does not satisfy the needs of the modern visitor. Though the virtual tour of Krasnoyarsk State Museum of Regional Studies is a nice visual trip around the exposition, the information society has high demands in the information content of such resources. The tour lacks some comments to the exposition in general and to some individual items, audio comments, possibility of opening additional "windows" with other pictures of the item, information about it and how it was developed in the culture of the people. With such need for highly detailed information on the ethnographic collection and its associated archives, publications of the Krasnoyarsk Museum are greatly sought for. The Museum has published its exposition guidebook; photo albums and ethnographic exposition catalogues (including electronic catalogues "Nganasan cultural items in the collection of Krasnoyarsk Regional Museum", "Collection of shaman's drums, cases and beats in the collection of the Krasnoyarsk State Museum of Regional Studies" and "Siberian ethnography in the works by Krasnoyarsk artists Karatanov A.I., Lekarenko A.L., Vargin A.G.”, photo albums "Yenisei Region ethnoses" and "Turukhansk Expedition of the Transpolar Population Census 1926-27", electronic teaching aid "History and culture of the Yenisei Region peoples" based on the museum collection). To expand the audience with the actualization of the cultural heritage of small-numbered indigenous peoples, ethnographic collections of the regional museum centres take part in travelling exhibitions. Such experience has been implemented by Evenki Museum of Regional Studies, Taymyr Reserve Museum of Nature and Ethnography by organizing travelling expositions on National Dolgan and Nganasan clothes.

At the same time, the Krasnoyarsk Territory (Krai) has had experience of actualization of the cultural heritage of the indigenous peoples by means of such efficient post-modern practices as reproduction of the ethnical environment with the opportunity of visit through the ethnographic tourism practices. An example is the mentioned Ethnography Museum on Lama lake. The Museum stands on the bank of Lama lake in front of Shaytan mountain, and works since 1997 in the territory of the tourist facility of the private Putoransky natural park located in Putorana State Nature Reserve. Today the central facility of the private reserve includes some guesthouses and a separate residence for the staff consisting of the representatives of the indigenous peoples of Taymyr, who live there all year round. In fact, the facility on Lama lake is an attempt of organizing an ethnic village-time museum. The main methods of actualizing the cultural heritage of the indigenous peoples of Taymyr, the Dolgans, Nganasans, Enets, is communication with the representatives of the people, immediate visit into their life and activities, as well as the exhibit collection (counting over a thousand 
items, mostly belonging to Nganasan culture) that can be also used in practice. In this case, the post-modern sociocultural practices are in action: a high-degree interactive museum in the form of an ethnical village located in the original environment with the opportunity of learning the ethnical traditional activities. At the same time, the museum is a part of the touristic facility, a component of a commercial project, which means that it is a combination of industrial and post-industrial sociocultural practices. Along with that, considering the remoteness of the Ethnography Museum and hard accessibility of the facility, the collection owners use one of the modern academic practices, which is reaching the wide audience through the published catalogue. The full catalogue of the Ethnoraphy Museum on Lama lake was published in 2010; its material is divided into the following sections: 1) collection of clothes, footwear, household items; 2) collection of labour tools, hunting, fishing, reindeer breeding accessories (multiple decorated deer head gear, harness, including ceremonial burial harness), labour tools; 3) shamanistic attributes: beds, shaman accessories. The comments describe the items presented in the catalogue with the data of arrival of this or that item into the collection, comparison of similar items, data on the functioning and use of the items including whole ritual description. We may say that as a project on actualization of the cultural heritage of the indigenous population of the Taymyr, Ethnography Museum on Lama lake synthesizes a whole spectrum of pre-modern, modern and post-modern sociocultural practices.

Field research of the Siberian Federal University also proves the active position of Folk craft centres and various cultural facilities, such as Folk craft centre in Khatanga (workshops: providing rooms, material, etc., participation in contests, education at Taymyr College in Dudinka), Folk craft centre in Dudinka, Taymyr
College in Dudinka ("Decorative and applied art and folk crafts (by types)" department), House of Culture, Craftsmen Gild in Baykit etc.

\section{Conclusion}

Decorative and applied art mostly performs the function of a bearer of cultural information on the basic values of the indigenous peoples (such as, Evenki beadwork), and this form of culture can be referred to as one of the longest-living means of involving pre-modern sociocultural practices into the modern society practices. The rise and growing topicality of the ethnical decorative and applied art is typical of the Evenki of the Krasnoyarsk Territory (Krai), since the majority of the young population has a national costume in their stock of clothes, and national ceremonial clothes are still produced. Among other nations, the highest percentage of keeping traditional clothes is shown by the Nenets, but there is no data on the national costume production today. For the indigenous peoples of the Krasnoyarsk Territory (Krai), decorative and applied art actively functions as a means of national presentation, involved into the commercial practices of souvenir productions, opening workshops at fairs and exhibitions, as well as conceptual presentation events.

In the process of preservation of the cultural heritage of the indigenous population of the Krasnoyarsk Territory (Krai) by means of actualization a great role is still played by the academic approach: conservation, museumification, research and scientific reconstruction of the traditional sociocultural practices of the ethnicities. In the academic aspect, cultural heritage acts as systematic basic knowledge used for finding genetic relations of some modern phenomena with the past understood as originality, including some current practices into traditions, involving the tradition into the modern contemporariness of 
the small-numbered indigenous peoples. At the modern stage, museumification combines several formats. Its classic foundation is still the display of the scientifically reconstructed tradition in its various forms, scientific description and studies of the museum resources, publication of the collection data in catalogues. Involving the museumification of the cultural heritage of the small-numbered indigenous peoples of the Krasnoyarsk Territory (Krai) into modern and post-modern sociocultural practices (commercial, educational, visual-technological etc.) served as a basis for the emergence of new efficient methods of its actualization and preservation. They include the "concept museum" expositions, educational events in the museum environment, interactive exposition with the opportunity of trying the exhibits in practice, modeling of the ethnocultural environment in order to create a comprehensive image of the people, including the ethno village format. Such efficient means of translating the ethnocultural heritage of the ethnicities as a virtual museum tour or a partial exhibition of the ethnographic collection online are still unfairly underestimated by the majority of the museum centres; an alternative popularization method, however, is the publication practices.
At the same time, the region has experience of the virtual ethnographic exposition tour; such opportunity is provided by Krasnoyarsk State Museum of Regional Studies, but the informative capacity of this means of actualization of the cultural heritage of small-numbered indigenous peoples is still limited. Another important element of actualization of the cultural heritage of the small-numbered indigenous peoples of the Krasnoyarsk Territory (Krai) is educational activities in the context of the ethnographic expositions. The region has experience of running some education programmes within the museum expositions, also with some support from schools (regional component of general education); the programmes include some cycles of classes encompassing various aspects of culture of the indigenous peoples. This method is actively practiced by Krasnoyarsk Museum of Regional Studies, as well as museums of such remote territories as Dudinka, Tura, Turukhansk, and Khatanga.

A great role is also played by the activities of such local institutions as Houses of Culture, Folk Crafts Centres, college departments etc. Such practices need support on both local and regional levels.

\section{References}

Ammosova, E.E. (1994). Narodnye istochniki tvorchestva: Odezhda. Ukrasheniia. Bytovye izdeliia: Al'bom [Folk crafts sources. Clothes. Jewellery. Household items: Album]. Yakutsk, Bichik.

Amurova, O. (2004). Obryady $i$ geroicheskie skazaniia narodov Evenkii. Materialy I mezhregional'noy nauchno-prakticheskoy konferentsii «Modernizatsiia obrazovaniia v usloviiakh Kraynego Severa». Tura, 9-12 aprelia 2004 g. [Rituals and heroic legends of the Evenki peoples. Proceedings of the I interregional scientific-practical conference "Modernization of education in the Extreme North conditions"]. Krasnoyarsk, 191-195.

Anderson, D.Dzh. (1998). Tundroviki: ekologiya i samosoznanie taymyrskikh evenkov i dolgan. [Tundra people: Ecology and self-consciousness of the Taymyr Evenki and Dolgans]. Novosibirsk, Publishing house of the SB of RAS.

Batashev, M.S. (2013). Etnicheskaya istoriia korennykh narodov Eniseyskogo uezda XVII veka i ikh sud'by [Ethnical history of the indigenous peoples of the Yenisei province of the $17^{\text {th }}$ century 
and their fates], In: Zhurnal Sibirskogo federal'nogo universiteta. Gumanitarnye nauki [Journal of Siberian Federal University. Humanities], 6 (6), 842-869.

Brzakova, P. (2000). Goromomo-gorolo. Davnym-davno: evenkiyskie skazki, legendy, skazaniia [Goromomo-gorolo. Once upon a time: Evenki fairy tales, legends, stories]. Krasnoyarsk, Sibirskiy promysel.

Diianova, A.M. (2012). Kul'turnoe nasledie sibirskikh tatar v deiatel'nosti muzeev Zapadnoy Sibiri na sovremennom etape (na primere traditsionnykh religioznykh verovaniy): avtoreferat dis. ... kand. Kul'turologii [Cultural heritage of the Siberian Tartars in the activities of the Western Siberian museums in the modern time (based on traditional religious beliefs): author's abstract from the dissertation for the academic degree of the Candidate of Cultural Science]. Kemerovo.

Etnicheskaia istoriia narodov Severa [Ethnical history of the Northern ethnicities] (1982). Moskva, Nauka.

Fol'klor nentsev v zapisiakh 1911, 1937, 1946, 1953, 1965-1987 godov [The Nenets folklore in records of 1911, 1937, 1946, 1953, 1965-1987] (2001). Novosibirsk: Nauka.

Gabysheva, L.L. (2003). Slovo v kontekste mifopoeticheskoy kartiny mira (na materiale iazyka $i$ kul'tury iakutov) [Word in the context of the mythopoetic world outlook (based on Yakut culture and language)], Moscow.

Gavrilov, I.K., Batashev, M.S., Makarov, N.P. (2017). Comprehensive ecological and ethnographic expedition to Evenkia. Nature and man, In: Severnye arhivy $i$ ekspeditsii [Northern archives and expeditions], 03 (1), 84-90.

Geroicheskiy epos dolgan-olonkho [Dolgan-Olonkho heroic epos] (2008). Krasnoyarsk.

Grishina, N.M. (2010). Rol' fol'klora v sokhranenii kul'turnogo naslediia ketov. Prieniseyskaia Sibir' kak lingvoregion: materialy I Mezhvuzovskoy nauchno-prakticheskoy konferentsii s mezhdunarodnym uchastiem, posviashchennoy pamiati V.N. Rogovoy, Krasnoyarsk, 2-10 noiabria $2009 \mathrm{~g}$. [Role of folklore in the preservation of the Ket cultural heritage. The Yenisei Siberia as a linguistic region: Proceedings of the I Intercollege scientific and practical conference with international participation dedicated to the memory of V.N. Rogovaia]. Krasnoyarsk, 156-161.

Habek, J.O. (2005). What it means to be a herdsman the practice and Image of Reindeer Husbandry among the Komi of Northern Russia.

Il'beykina, M.I. (2013). Rol'vizual'noy antropologii v sotsial'nom konstruirovanii tsennostey: avtoreferat dis. ... kand. filos. nauk. [Role of visual anthropology in the social values construction: author's abstract from the dissertation for the academic degree of the Candidate of Philosophy]. Krasnoyarsk. Available at: http://research.sfu-kras.ru/sites/research.sfu-kras.ru/files/Ilbeykina_17_k.pdf

Ivanov, S.V. (1963). Ornament narodov Sibiri kak istoricheskiy istochnik (po materialam XIXnachala XX veka) [Siberian ethnic ornaments as a historical source (based on materials dated to the $19^{\text {th }}$-early $20^{\text {th }}$ centuries)]. Moskva, Leningrad, Publishing house of the USSR Academy of Sciences.

Ivanov, V.Kh. (2001). Etnokul'turnye vzaimosviazi $i$ vzaimovliianiia u narodov Severo-Vostoka Sibiri: Po materialam traditsionnogo dekorativno-prikladnogo iskusstva [Ethnocultural relations and mutual influence of the peoples of the Siberian North-East: based on the traditional decorative and applied arts]. Novosibirsk, Nauka.

Kanyba, O.V. (2013). Osobennosti formirovaniia istoriko-kul'turnykh brendov territoriy [Peculiarities of forming the historical and cultural brands of territories], In: Vestnik Rossiyskogo novogo universiteta [New Russian University Newsletter], 2, 175-179. 
Khakkaraynen, M.V. (2007). Shamanizm kak kolonial'nyy proekt [Shamanism as a colonial project], In: Antropologicheskiy forum (AF) [Anthropological Forum (AF)] 7, 156-190.

Kolesnik, M.A. (2016). Decoration of children's literature of the indigenous peoples of the North, Siberia and the Far East. Journal of Siberian Federal University. Humanities \& Social Sciences, 9 (9), 2044-2059. Available at: http://dx.doi.org/10.17516/1997-1370-2016-9-9-2044-2059

Koptseva, N., Kirko, V. (2014a). Ethic identification of indigenous people of the Siberian. Arctic American Journal of Applied Sciences, 11 (9), 1574-1578. Available at: http: 10.3844/ ajassp.2014.1574.1578

Koptseva, N.P., Kirko, V.I. (2014b). Post-soviet practice of preserving ethnocultural identity of indigenous peoples of the North and Siberia in Krasnoyarsk region of the Russian Federation. Life Science Journal, 11 (7), 180-185.

Koptseva, N.P., Kirko, V.I. (2015). The impact of global transformations on the processes of regional and ethnic identity of indigenous peoples Siberian Arctic. Mediterranean Journal of Social Sciences, 6 (3), 217-224. Available at: http://dx.doi.org/ 10.5901/mjss.2015.v6n3s5p217

Koptseva, N.P., Khizhniakova, A.N., Reznikova, K.V. (2017). K voprosu o kontseptakh iazykov korennykh narodov Krasnoiarskogo kraia [To the question of linguistic aspects of the indigenous peoples of the Krasnoyarsk Territory (Krai)], In: Severnye arhivy i ekspeditsii [Northern archives and expeditions], 03 (1), 6-22.

Koptseva, N.P., Kirko, V.I., Nevzorov, V.N., Razumovskaya, V.A., Bukharova, E.B., Semenova, A.R. (2016). Traditional nature management areas as means of organizing the economic activities of the Siberian Arctic's indigenous minorities. International Review of Management and Marketing, 6 (5), 154-161.

Korennye malochislennye narody Severa i Sibiri v usloviiakh global'nykh transformatsiy (na materiale Krasnoiarskogo kraya). Chast' 1 [Small-numbered indigenous peoples of the North and Siberia under the conditions of global transformations (based on the material of the Krasnoyarsk Territory (Krai)] (2012). Krasnoyarsk, Siberian Federal University.

Korovushkin, D.G. (2017). The Boguchansk archaeological expedition of the Institute of Archeology and Ethnography, Siberian Branch of the Russian Academy of Sciences: Short Historical Sketch. In: Severnye arhivy i ekspeditsii [Northern archives and expeditions], 06 (2), 23-42.

Kotler, F., Asplund, K., Reyn, I., Khayder, D. (2005). Marketing mest. Privlechenie investitsiy, predpriiatiy, zhiteley i turistov $v$ goroda, kommuny, regiony i strany Evropy [Marketing of places. Attraction of investments, enterprises, residents and tourists into towns, communities, regions and European countries]. Saint Petersburg. Stockholm School of Economics in Saint Petersburg.

Krasnoiarskiy kraevoy kraevedcheskiy muzey: putevoditel' [Krasnoyarsk State Museum of Regional Studies: the Guidebook] (2002). Krasnoyarsk, KSMRS.

Krivonogov, V.P. (2008). Chulymtsy v nachale XXI veka: monografiia [The Chulyms in the early $20^{\text {th }}$ century: monograph]. Krasnoyarsk, V.P. Astafiev Krasnoyarsk State Pedagogical University.

Krivonogov, V.P. (2013). The Dolgans' ethnic identity and language processes. Journal of Siberian Federal University. Humanities \& Social Sciences, 6 (6), 870-881.

Kuropiatnik, M.S. (2006). Korennye narody v protsesse sotsiokul'turnykh izmeneniy: dis. ... $d$-ra sotsiol. nauk [Indigenous peoples in the process of sociocultural changes: Dissertation for the academic degree of a Doctor of Social Science]. Saint Petersburg. 
Libakova, N.M., Kolesnik, M.A., Sergeeva, N.A., Sertakova, E.A. (2017). Research opportunities in art anthropology based on the example of the bone carving works of Siberian masters. In: Sibirskiy antropologicheskiy zhurnal [Siberian anthropological journal], 06 (1), 22-34.

Libakova, N.M., Petrova, K.I. (2016). Children's literature of indigenous small-numbered peoples of the Krasnoyarsk Krai. Journal of Siberian Federal University. Humanities \& Social Sciences, 9 (9), 1977-1993. Available at: http://dx.doi.org/ 10.17516/1997-1370-2016-9-9-1977-1993.

Makarov, N.P. (2013a). Drevnie etapy kul'turogeneza narodov Krasnoiarskogo Severa [Ancient stages of culture genesis of the peoples of the Krasnoyarsk North], In: Zhurnal Sibirskogo federal'nogo universiteta. Gumanitarnye nauki [Journal of Siberian Federal University. Humanities], 6 (6), 816-841.

Makarov, N.P. (2013b). Arkheologicheskie klady izfondov Krasnoiarskogo muzeia kak istochnik po mirovozzreniiu drevnikh i traditsionnykh obshchestv. Sbornik nauchnykh trudov: $v 2 t$. [Archaeological treasures from the funds of Krasnoyarsk museum as a source for studying the world outlook of the ancient and traditional societies]. Irkutsk, Irkutsk State Technological University, V. 2, 79-82.

Makarov, N.P., Batashev, M.S. (2007). Istoriia i kul'tura narodov Severa Prieniseyskogo kraia [History and culture of the peoples of the Yenisei Region North]. Krasnoyarsk, OOO IPTs «KaSS».

Mal'kova, V.K., Tishkov, V.A. (2010). Kul'tura i prostranstvo. Kniga vtoraia: istoriko-kul'turnye brendy territoriy, regionov i mest [Culture and space. Book two: Historical and cultural brands of territories, regions, and places]. Moscow, Ethnography institute of RAS.

Mandryka, P.V. (2008). Step' i tayga: problema vzaimootnosheniy plemen rannego zheleznogo veka (po materialam Eniseyskogo Priangar'ia) [Steppe and tayga: problem of relationships between early Iron Age tribes (based on Yeniseisk Angara region], In: Zhurnal Sibirskogo federal'nogo universiteta. Gumanitarnye nauki [Journal of Siberian Federal University. Humanities], 1 (2), 261-269.

Mandryka, P.V. (2017). For the history of the archaeological research on the lower reaches of the Angara River. In: Severnye arhivy $i$ ekspeditsii [Northern archives and expeditions], 06 (2), 43-51.

Mandryka, P.V., Abdulina, Yu.A., Bykova, M.V. (2007). Arkheologicheskie issledovaniia Sibirskogo federal'nogo universiteta. Arkheologicheskie otkrytiia 2006 goda [Archaeological research of Siberian Federal University: Archaeological discoveries of the year 2006], 71-72.

Mify, skazki, predaniia mansi [Mansi myths, fairy tales, and legends] (2005). Novosibirsk, Nauka.

Mukhachev, A.D., Salatkin, V.G. (2007). Ekologicheskiy slovar' evenkov [Evenki environmental dictionary]. Krasnoyarsk.

Muratkasimova, A.M. (2010). Kharakteristika fol'klornykh traditsiy dolgan. Taymyrskie chteniya - 2010: sbornik dokladov [Dolgan folklore traditions. Taymyr Readings - 2010: collection of reports]. Norilsk, Norilsk Industrial Institute, part 1, 133-140.

Natsional'naia odezhda evenkov [Evenki national clothes] (1994). Yakutsk.

Naumov, D.N. (2012). Regional'naia identichnost' kak glavnyy faktor formirovaniia blagopriyatnogo brenda territorii (na primere KhMAO - YuGRY) [Regional identity as the main factor of making up an advantageous territorial brand (based on Khanty-Mansi Autonomous District-Yugry], In: Sovremennyye problemy nauki i obrazovaniia [Modern problems of science and education], 5, 3.

Nganasany: kul'tura naroda v atributakh povsednevnosti. Katalog Etnograficheskogo muzeia na ozere Lama [Nganasans: Culture of the people in the household attributes. Catalogue of the Ethnography Museum on Lama lake] (2010). Norilsk, APEKS. 
Oegir, N.K. (2006). Chtob ne gas koster...: evenkiyskie narodnye skazki, zagadki, primety, nastavleniia, stikhi [Do not let the fire fade...: Evenki folk fairy tales, riddles, superstitutions, fables, poems]. Krasnoyarsk, Sibirskie promysly.

Official website of D.S. Kargapolov Achinsk Museum of Regional Studies. Available at: http:// ачинский-музей.рф/

Official website of A.I. Herzen State Pedagogical University of Russia Institute of the Northern Peoples. Available at: http://www.herzen.spb.ru/main/structure/inst/ins/

Official website of Krasnoyarsk State Museum of Regional Studies. Available at: http://www. kkkm.ru

Official website of N.M. Mart'ianov Minusinsk Museum of Regional Studies. Accessed on: http:// музей-мартьянова.рф/

Official website of Taymyr Museum of Regional Studies. Available at: http://www.taimyr-museum.ru

Ornamenty narodov Taymyra [Ornaments of the Taymyr peoples] (1994). Dudinka, Taymyrpressfoto.

Peretiatko, T. (2004). Fol'klor narodov Kraynego Severa: istoki i traditsii. Materialy I Mezhregional'noy nauchno-prakticheskoy konferentsii «Modernizatsiia obrazovaniia $v$ usloviiakh Kraynego Severa», Tura, 9-12 aprelia 2004 g. [Folklore of the Extreme North peoples: origins and traditions. Proceedings of the I Interregional Scientific and Practical Conference "Modernization of education in the Extreme North conditions] Krasnoyarsk, 184-191.

Predmety shamanskogo kul'ta korennykh narodov Taymyra: katalog kollektsii [Shaman cult items of the Taymyr peoples: Collection catalogue] (2008). Dudinka.

Prytkova, N.F. (1970). Odezhda narodov samodiyskoy gruppy kak istoricheskiy istochnik. Odezhda narodov Sibiri: sbornik statey MAE [Samoyed peoples' clothes as a historical source. Siberian ethnical clothes: collection of articles], 3-99.

Rethmann, P. (1997). Chto delat? Ethnography in the Post-Soviet Cultural Context. In: American Antropologist, 99 (4), 770-774.

Reznikova, K.V., Zamaraeva, J.S., Kistova, A.V., Pimenova, N.N. (2014). The current state of traditional socio-cultural practices of indigenous peoples of the North (on the example of cultures of Selkups, Nenets and Essey Yakuts). In: Life Sci J, 11(12), 126-132.

Reznikova, K.V. (2013). Preservation and Transformation of Certain Aspects of the Traditional Way of Life of the Indigenous and Small-Numbered Peoples of the North, Living in the Settlements (Posyolki) of Turukhansk and Farkovo. Journal of Siberian Federal University. Humanities \& Social Sciences, 6 (6), 925-939.

Reznikova, K.V. (2017). Sovremennoe sostoianie sel'kupov Krasnoiarskogo kraia po materialam polevykh issledovaniy (iiun' 2010 g.) [Modern status of the Selkups of the Krasnoyarsk Territory (Krai): based on field research of June 2010], In: Severnye arkhivy i ekspeditsii [Northern archives and expeditions], 03 (1), 23-40.

Robbek, M.E., Robbek, V.A. (2004). Kraski severnogo siianiia v uzorakh masterits: Prikladnoe iskusstvo evenov Berezovki [Aurora borealis colours in the northern ornaments: Applied art of Berezovka Evens]. Novosibirsk, Nauka.

Saf'iannikova, T.M. (2006). Raduga krasok sonkana [Sonkan rainbow of colours]. Krasnoyarsk, Sibirskie promysly. 
Saf'iannikova, T.M. (2008). Ornament i ukrasheniia evenkov [Evenki ornaments and jewellery]. Krasnoyarsk, Sibirskie promysly.

Savel'ev, Yu.V. (2011). Osobennosti formirovaniia brenda territorii na osnove ee kul'turnoistoricheskogo naslediia. Uchenye zapiski Petrozavodskogo gosudarstvennogo universiteta: Materialy IX Kongressa etnografov i antropologov Rossii [Peculiarities of territorial brand development based on its cultural and historical heritage. Scientific notes of Petrozavodsk State University: Proceedings of the IX Congress of ethnographers and anthropologists of Russia]. 3, 88-93.

Semenova, A.A., Bralkova, A.V. (2011). Vizualizatsiia kontsepta «sever» v izobrazitel'nom iskusstve [Visualization of the North concept in visual art], In: Zhurnal Sibirskogo federal'nogo universiteta. Gumanitarnye nauki [Journal of Siberian Federal University. Humanities], 4 (4), 476-491.

Seredkina, N.N., Smolina, M.G., Kistova, A.V. (2017). An Epic's Impact on the Tales of the Indigenous Peoples of the North and Siberia. Sibirskiy antropologicheskiy zhurnal [Siberian anthropological journal], 06 (1), 62-73.

Simonova, V.V. (2008). Interpretatsii prostranstva predstaviteliami malochislennykh narodov Severa $v$ razlichnykh sotsiokul'turnykh sredakh: dis. ... kand. sotsiol. nauk. Moskva, Tsentr issledovaniia mezhnatsional'nykh otnosheniy Instituta sotsiologii RAN [Interpretation of space by the small-numbered peoples of the North in various sociocultural media: Dissertation for the academic degree of the Candidate of Social Science. Moscow, Centre for research of international relations of the Sociology Institute of RAS].

Sitnikova, A.A. (2016). Nganasan children literature: history and specifics. Journal of Siberian Federal University. Humanities \& Social Sciences, 9 (9) 2005-2012. Available at: http://dx.doi.org/ 10.17516/1997-1370-2016-9-9-2005-2012.

Slezkin, Yu. (2008). Arkticheskie zerkala: Rossiia i malochislennye korennye narody Severa [Arctic mirrors: Russia and small-numbered indigenous peoples of the North]. Moscow, Novoe literaturnoe obozrenie.

Trifonova, L.N. (2006). Chelovek sredi zhivotnykh (mifologicheskie istoki evenkiyskikh skazok) [Man among animals (mythological origin of Evenki fairy tales)], In: Observatoriya kul'tury: zhurnalobozrenie [Observatory of Culture: magazine-review], 6, 85-89.

Turukhanskaia ekspeditsiia Pripolyarnoy perepisi: etnografia i demografiia malochislennykh narodov Severa [Turukhansk expedition of the Transpolar population census: ethnography and demography of the small-numbered indigenous peoples of the North] (2005). Krasnoyarsk, Polikor.

Vasilevich, G.M. (1969). Evenki: Istoriko-etnograficheskie ocherki (18-nachalo 20 vv.). [Evenki: historical and ethnographic essays (18-early 20 th centuries)]. Leningrad, Nauka.

Volchenko, S. (2006). Material'naia i dukhovnaia kul'tura korennykh narodov Sibiri. Taymyrskie chteniia - 2006: sbornik dokladov [Material and spiritual culture of the small-numbered indigenous peoples of Siberia. Taymyr Readings - 2006: collection of reports]. Norilsk, Norilsk Industrial Institute.

Zamaraeva, Y.S., Reznikova, K.V., Pimenova, N.N. (2017). History of anthropological studies on the indigenous peoples of Siberia, In: Sibirskiy antropologicheskiy zhurnal [Siberian anthropological journal], 06 (1), 6-21.

Zhukovsky, V.I. (2011). Teoriia izobrazitel'nogo iskusstva [Visual art theory]. Saint Petersburg, Aleteia. 
Zhukovsky, V.I., Koptseva, N.P. (2010). Iskusstvo kak zhiznennaia neobkhodimost'. Proizvedenie izobrazitel'nogo iskusstva. Iskusstvo i obrazovanie [Art as vital necessity. Work of visual art. Art and education], 3, 5-29.

\title{
Актуальное состояние декоративно-прикладного искусства коренных народов, проживающих на территории Эвенкийского и Таймырского муниципальных районов (экономические и социально-культурные практики)
}

\author{
А.В. Кистова, Н.Н. Пименова \\ Сибирский федеральный университет \\ Россия, 660041, Красноярск, пр. Свободныий, 79
}

Исследование отражает современное состояние сочиокультурных практик коренных народов Красноярского края, в частности Эвенкийского и Таймырского муниципальных районов, на основе статистических данных и результатов полевых исследований ведущих этнографов и культурологов, а также экспедиций Сибирского федерального университета.

В статье рассматриваются актуальные формы существования декоративно-прикладного искусства коренных народов края в качестве одного из ведущих средств сохранения культурного ядра народов Севера.

Среди существующих экономических и социально-культурных практик сохранения культурного наследия коренных народов Севера и Сибири в Красноярском крае преобладают формы академического подхода - музеефикачия, консервация, научное исследование и реконструкиия. Под воздействием практик модерна и постмодерна в крае развиваются также эффективные способы актуализачии и сохранения культурного наследия коренных народов.

Ключевые слова: декоративно-прикладное искусство, коренные народы Красноярского края, Эвенкийский муниципальный район, Таймырский муниципальный район.

Исследование выполнено при поддержке краевого государственного автономного учреждения «Красноярский краевой фонд поддержки научной и научно-технической деятельности» в рамках реализачии проекта: "Декоративно-прикладное искусство коренных малочисленных народов Красноярского края: современное состояние, перспективы развития.

Исследование выполнено при финансовой поддержке Российского фонда фундаментальных исследований, Правительства Красноярского края, Красноярского краевого фонда поддержки научной и научно-технической деятельности в рамках научного проекта № 17-16-24601.

Научная специальность: 24.00.00 - культурология. 